\title{
Influence of roadside pollution on the phylloplane microbial community of Alnus nepalensis (Betulaceae)
}

\author{
S.R. Joshi \\ Department of Biotechnology \& Bioinformatics, School of Life Sciences, North-Eastern Hill University, Mawkynroh, \\ Umshing, Shillong 793022, Meghalaya, India; srjoshi2006@yahoo.co.in; srjoshi2006@gmail.com
}

Received 08-I-2007. Corrected 30-VI-2008. Accepted 31-VII-2008.

\begin{abstract}
The North Eastern region of India is undergoing industrial development at a faster rate than expected. Roads form the main system of transportation and communication owing to the hilly topography of the region. Automobiles discharge a number of gaseous and trace metal contaminants. Human activities like stone grinding, road construction and sand milling also increase the atmospheric dust and heavy metal contaminant level. These contaminants get settled on leaf surfaces at roadsides and enter in contact with phylloplane microorganisms. This study compares microorganisms on leaf surfaces of alder (Alnus nepalensis (Betulaceae)) on roadside and non-roadside environments. Two sites dominated by alder were selected. One at a busy road intersection on the National Highway no. 44 in Shillong with high traffic density (8 000-9 000 heavy vehicles/day), taken as the polluted site and the other one in a forest approximately $500 \mathrm{~m}$ away from the roadside considered as the unpolluted site. Analysis of phylloplane microorganisms, lead, zinc, copper, cadmium and sulphur was carried out from leaves. The bacterial population was higher at the unpolluted site. Bacterial population showed a significant negative correlation with lead, zinc, copper, cadmium and sulphur. Similarly, fungal population was higher at the unpolluted site. A total of 29 fungal species were isolated from the phylloplane of $A$. nepalensis (polluted site 16 species; unpolluted site 28 species). Some fungal forms like Mortierella sp., Fusarium oxysporum and Aureobasidium pollulans were dominant in the polluted site. Numbers of phylloplane fungi and bacteria were significantly reduced in the polluted site. The correlation coefficient indicated a detrimental effect of metals like lead, zinc, copper, cadmium and sulphur on the microbial community of leaf surfaces. The specificity of certain fungi to the unpolluted site may be attributed to their sensitivity to pollution. The predominance of Aureobasidium pollulans, Fusarium oxysporum and Mortierella sp. in the polluted site may be due to their resistance to pollutants in roadside conditions. Rev. Biol. Trop. 56 (3): 1521-1529. Epub 2008 September 30.
\end{abstract}

Key words: Alnus nepalensis, roadside, pollution, heavy metals, phylloplane, microbial community.

Leaf surfaces of roadside trees are exposed to various trace metal and gaseous contaminants discharged from the vehicles. The increasing number of vehicles running on petrol and diesel fuel produces excessive fumes containing tar particles and other metal contaminants due to the incomplete combustion of fuel. Certain other human activities like road construction, sand milling, stone grinding, etc. also add to the atmospheric dust and trace contaminants which get settled on the leaves of roadside trees. The microbial community of the phylloplane may be altered by the gaseous and particulate atmo- spheric pollutants (Saunders 1971, Mowll et al. 1985)

The relationship between air pollution and microorganisms is an important and incompletely appreciated topic (Saunders 1973, Manning 1975). Organisms that exist in the phylloplane are particularly vulnerable to the influence of air contaminants (Smith 1976a). Chemical sprays on the leaf surface is reported to reduce bacterial, filamentous fungal and yeast communities diversity of mango phylloplane (De Jager et al. 2001). Air pollution has been reported to bring about change in the lichen cover in a 
tropical habitat over a period of time (MongeNajera et al. 2002). Mould fungi were found to be the most numerous of the microbial community in the air on the premises of a landfill site (Malecka-Adamowicz et al. 2007).

While there has been some studies on the effects of industrially derived heavy metal pollution on leaf surface microorganisms (Gingell et al. 1976, Bewley 1980, Bewley et al. 1980), little work has been done on the effects of heavy metal and trace contaminants on leaf surface microorganisms in the roadside urban environment in general (Smith 1971, Smith 1976a, Smith 1976b, Smith 1977, Swailesh et al. 2004) and on the effects of vehicular pollution on phylloplane microorganisms in particular (Mowll et al. 1985) Therefore, a study to understand the impact of vehicular air pollution on the phylloplane microorganisms of roadside trees (Alnus nepalensis) was carried out.

\section{MATERIALS AND METHODS}

Selection of site: two forest sites dominated by alder trees, A. nepalensis, located a busy road intersection of the National Highway no. 44 Shillong (altitude 1730 a.s.1, latitude $25^{\circ} 34^{\prime}$, longitude $91^{\circ} 46^{\prime} \mathrm{E}$ ) with traffic density (8 000-9 000 heavy vehicles/day) taken as the polluted site while the other one was approximately $500 \mathrm{~m}$ away from the roadside and considered as the unpolluted site. While selecting care was taken to ensure similarity in topography and micro-environmental conditions.

Climate of the study site: the climate of the study sites is typically monsoonic. The south-west monsoon and north-east winter winds influence the climate of the area. The climate of the study area can be divided into four marked seasons (i) the monsoon season of heavy rainfall (May-September) due to southwest monsoon, (ii) a transitional period of low rainfall, autumn season (October-November) due to retreating monsoon, (iii) a winter season (DecemberFebruary) with scattered low rainfall and (iv) a windy dry summer (March-April). The average monthly rainfall of the study area ranged from $2.1 \mathrm{~mm}$ to $421.2 \mathrm{~mm}$. The average minimum and maximum temperature varied from $6.1{ }^{\circ} \mathrm{C}$ to $18.0{ }^{\circ} \mathrm{C}$ and $15.1{ }^{\circ} \mathrm{C}$ to $24.3^{\circ} \mathrm{C}$ respectively. The average relative humidity ranged between $68.5 \%$ to $89 \%$ (Fig. 1 ).

Isolation of phylloplane microorganisms: for the isolation of micro fungi and bacteria from the leaf surface, dilution plate method was followed (Dickinson 1971). Ten samples of leaves were collected in sterilized container at a bimonthly interval for one year from ten different alder plants at each site and brought to the laboratory. The microbial assay was carried out within $24 \mathrm{~h}$ of sampling. The leaf samples were cut into small pieces with sterilized scissor in a laminar flow chamber to avoid contamination and mixed thoroughly. One gram (on wet weight basis) sample was taken in a $250 \mathrm{ml}$ sterilized conical flask containing $100 \mathrm{ml}$ of sterilized distilled water. Flasks were shaken vigorously for 30 minutes

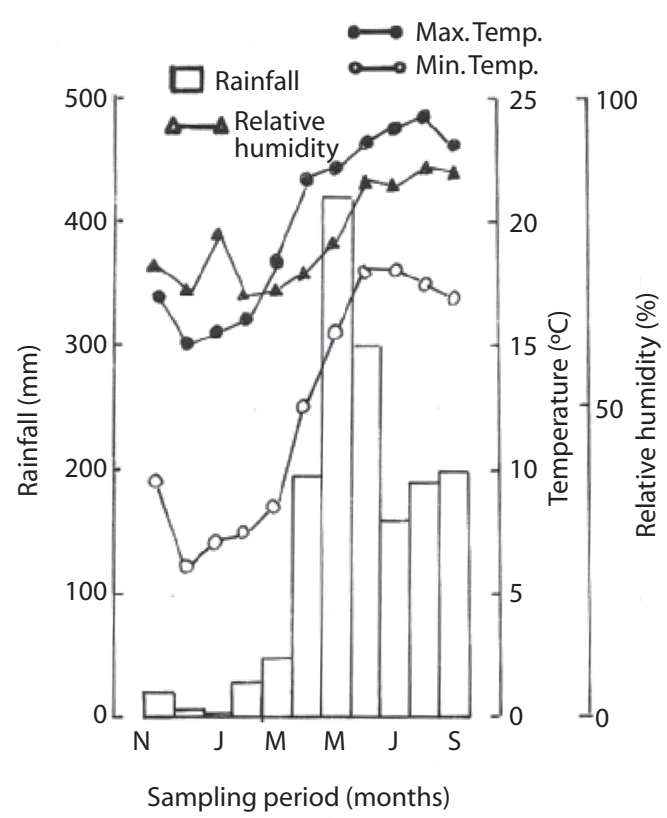

Fig. 1. Monthly variation in rainfall, ambient temperature (minimum and maximum) and relative humidity of the study site during the study period. 
to detach the surface propagules. A suspension of 1:100 was then obtained. $10 \mathrm{ml}$ of this suspension was transferred aseptically to a 250 $\mathrm{ml}$ conical flask containing $90 \mathrm{ml}$ of sterilized distilled water to get a dilution of 1:1 000. The process was repeated to get a suspension of 1:10 000 dilution. For the isolation of fungi and bacteria, a 1:1 000 and 1:10 000 dilutions respectively was used.

$0.5 \mathrm{ml}$ suspension was transferred aseptically into sterilized petriplates containing $15 \mathrm{ml}$ of sterilized solidified Rose Bengal agar (Martin 1950) and Nutrient agar medium (Difco-manual. 1953) for fungi and bacteria respectively. Three replicates were maintained in each case. The petriplates for microfungi and bacteria were incubated at $25 \pm 1{ }^{\circ} \mathrm{C}$ and $30 \pm 1{ }^{\circ} \mathrm{C}$ for five days and for $24 \mathrm{~h}$ respectively. Number of fungi and bacteria was calculated as colony forming units (CFU) per gram dry leaf, taking into account the dilution factor and moisture content of leaf.

The relative abundance of fungi was calculated by using the following formula

$$
\text { Relative abundance }(\%)=\frac{\text { Total number of CFU of the individual }}{\text { Total number of CFU of all the species }} \times 100
$$

Fungal diversity, species richness and similarity index: the index of fungal diversity was calculated using Shannon's index of diversity (Shannon 1948) as

$$
\text { Shannon's index }(\mathrm{H})=\frac{-(\mathrm{ni})}{\mathrm{N}} \quad \frac{\log (\mathrm{ni})}{\mathrm{N}}
$$

Where:

$\mathrm{ni}=$ relative abundance of species

$\mathrm{N}=$ total relative abundance

Similarity index was calculated by Sorenson's similarity index (Sorenson 1948) as

$$
\text { Similarity index }=\frac{2 \mathrm{C}}{\mathrm{A}+\mathrm{B}} \times 100
$$

Where:

$A=$ Number of fungal species in unpolluted site

$\mathrm{B}=$ Number of fungal species in polluted site $\mathrm{C}=$ Species common in $\mathrm{A}+\mathrm{B}$

Species richness index was calculated as

$$
\text { Species richness }=\frac{\mathrm{S}-1}{\log \mathrm{N}}
$$

Where:

$\mathrm{S}=$ Number of fungal species

$\mathrm{N}=$ Total number of fungi (CFU)

Analysis of lead, zinc, copper and cadmium in leaf sample: $0.2 \mathrm{~g}$ of dried powdered leaf samples in triplicate were digested in $20 \mathrm{ml}$ conc. $\mathrm{HNO}_{3}$. Extracts were filtered and made up to $50 \mathrm{ml}$ with double distilled water. The extent of metal binding by filters was checked using metal stock solution and was found negligible (Proctor et al. 1980). Samples were analysed on Perkin Elmer 2380 Atomic absorption spectrophotometer after appropriate dilution with distilled water.

The concentration of metal was calculated as

Total metal $(\mu \mathrm{gg}-1)=\frac{\mathrm{c}(\mathrm{ppm}) \times \text { solution volume }(\mathrm{ml})}{\text { Sample weight }(\mathrm{g})}$

Where:

$\mathrm{c}=\mathrm{ppm}$ metals obtained from the standard curve

Analysis of sulphur: the samples were oven dried at $80{ }^{\circ} \mathrm{C}$ for $24 \mathrm{~h}$, powdered, ashed at $450{ }^{\circ} \mathrm{C}$ for $12 \mathrm{~h}$ in a muffle furnace and the ash was dissolved in conc $\mathrm{HNO}_{3}$. Total sulphur 
was determined by the turbidimetric method (Allen 1974).

Total sulphur in leaves was calculated as

Total sulphur $(\mu \mathrm{gg}-1)=\frac{\mathrm{c}(\mathrm{ppm}) \mathrm{x} \text { solution volume }(\mathrm{ml})}{\text { Sample weight }(\mathrm{g})}$

Where:

$\mathrm{c}=$ ppm sulphur obtained from the standard curve

Statistical analysis: the coefficient of correlation (r) was calculated using Karl Pearson's coefficient of correlation (Zar 1976). Statistical analysis of data was done by performing Lattic Square Design (LSD).

\section{RESULTS}

Bacterial community: phylloplane bacterial population showed a marked seasonality with its maxima in July and minima in January. Number of bacteria was significantly higher at unpolluted site compared to polluted ones (Fig. 2).

It showed a significant negative correlation with the concentration of lead, zinc, copper, cadmium and sulphur in leaf at polluted
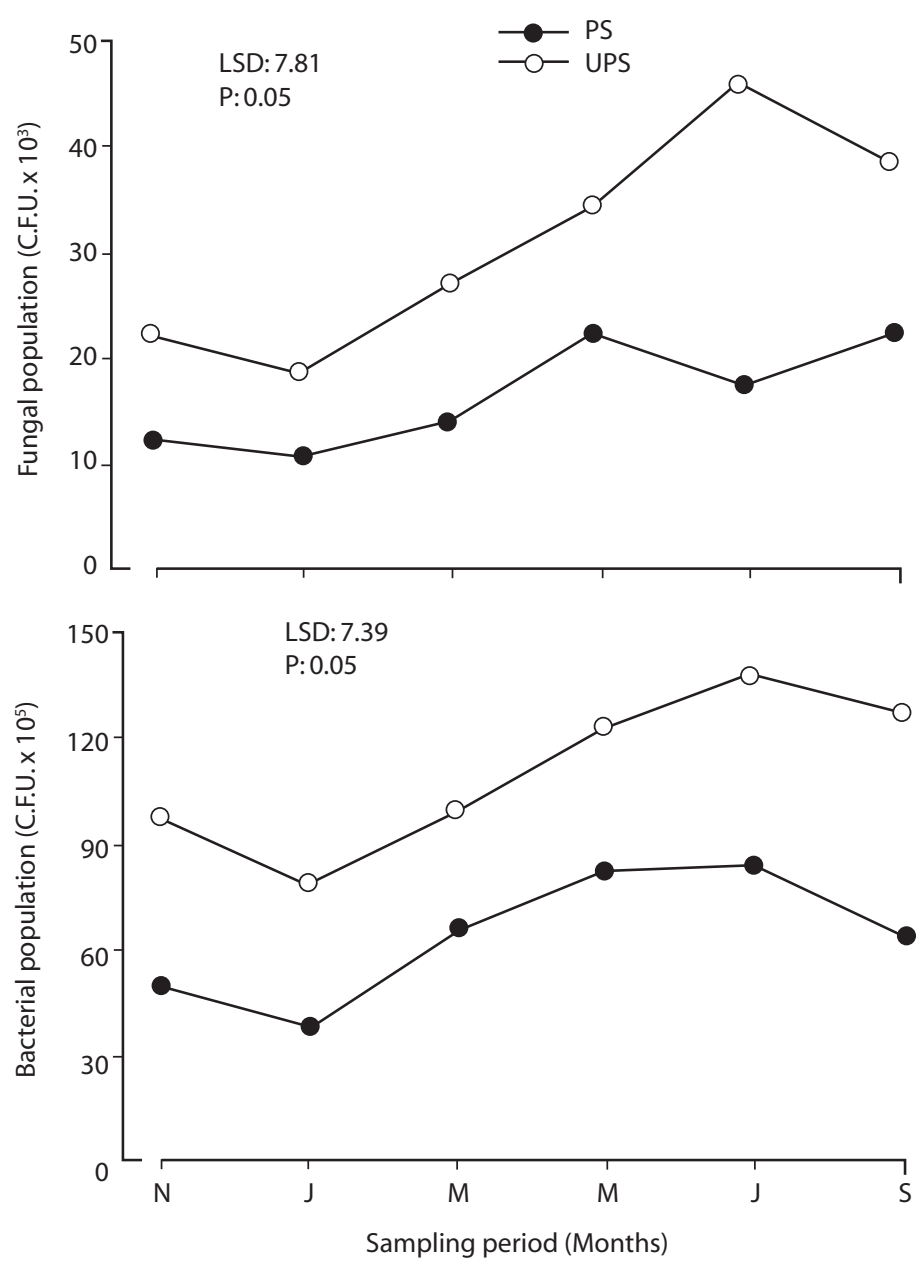

Fig. 2. Bimonthly variation in the microfungal and bacterial population (CFU) in the leaf surface of alder at polluted (PS) and unpolluted (UPS) sites. 
site. A significant positive correlation between bacterial population and ambient temperature was also observed (Table 3 )

Microfungal community: the number of microfungi in phylloplane was maximum at the unpolluted site in July and minimum in January (Fig. 2). Fungal Composition at two sites varied significantly.

A total of 29 microfungal taxa were isolated from the phylloplane of alder. Of these, 28 species were recorded from unpolluted site and 16 species from polluted ones. Cladosporium cladosporioides Aspergillus fumigatus, A. Niger, Paecilomyces variotii, Sporobolomyces roseus, Absidia spinosa, Epicoccum purpurascens, Geotrichum candidum, Cunninghamella echinulata, Curvularia lunata, Acremonium sp., Oidiodendron sp. and Chaetomium sp. were specific to unpolluted site whereas, Mortierella sp. was isolated only from the polluted site. CFU of Aureobasidium pollulans and Fusarium oxysporum were more and were dominant in polluted site. Maximum fungal diversity was observed in the month of May and minimum in January in both the sites (Table 1).

Fungal diversity and species richness was more in unpolluted site than the polluted site (Table 2).

A significant negative correlation was observed between the number of CFU and the concentration of $\mathrm{Pb}, \mathrm{Zn}, \mathrm{Cu}, \mathrm{Cd}$ and $\mathrm{S}$ in leaf at the polluted site. Significant positive correlation between rainfall and number of microfungi was also observed (Table 3).

Seasonal change in $\mathrm{Pb}, \mathrm{Zn}, \mathrm{Cu}, \mathrm{Cd}$ and $S$ contents: considerable differences in the level of heavy metals and sulphur on leaves were observed at both the sites (Fig. 3). Their quantity was significantly greater at polluted site than unpolluted one. Maximum amount of pollutants was observed in January and minimum in May exhibiting a negative correlation with the rainfall. The variation in levels of $\mathrm{Pb}, \mathrm{Zn}, \mathrm{Cu}$, $\mathrm{Cd}$ and $\mathrm{S}$ was not significant between samples collected at different samplings from unpolluted site as was seen in polluted site (Fig. 3).

\section{DISCUSSION}

Number of phylloplane fungi and bacteria was significantly reduced in polluted site as compared to the unpolluted site and correlation coefficient analysis of data indicated the detrimental effect of the pollutants on the leaf surface microbial community. The findings were supported by industrially derived metal pollution studies (Bewley 1980, Bewley et al. 1980) and chemical sprays on the leaf surface (DeJager et al. 2001). Microfungal species composition and their diversity in the phylloplane was directly correlated to the roadside pollution as suggested for bacteria in dusty hemlock leaves (Manning 1971). Similar change in lichen cover was correlated to air pollution in a tropical forest (Monge-Najera et al. 2002)

The specificity of certain fungi to unpolluted site may be attributed to their sensitivity to the pollution. Whereas, the predominance of A. pollulans, F. Oxysporum, Mortierella sp. in the polluted site was due their resistance to pollutants and altered sporulation capacity or spore life span. Stimulatory effect of pollutants on the microbial number but not the species composition supports our findings that the stressed or hostile environmental conditions enhance the production of spores ensuring their survival or movement to suitable environments (Manning 1971). The greater density of yeast cells and other metal tolerant fungi was attributed to their ability to utilize elements as nutrients within the pollutant dust and the beneficial effects of which might outweigh the effect of pollutant toxicity (Bewley 1980). The complexity of interactions between phylloplane microorganisms were affected differentially by the pollutants due to their sporulation capacity (Fritze et al. 1993).

A noteworthy difference in the diversity of microfungal species between polluted and unpolluted sites was attributed to the inhibitory effect of vehicular exhausts and trace contaminants at the roadside (Mowll et al. 1985). Drastic change in the number of fungi at polluted site was directly correlated to the toxicity 
TABLE 1

Relative abundance (\%) of fungal species on leaf surface of Alnus nepalensis at polluted and unpolluted sites

Fungal species

Polluted site

Unpolluted site

\begin{tabular}{|c|c|c|c|c|c|c|c|c|c|c|c|c|}
\hline - 1 & Nov & Jan & Mar & May & Jul & Sep & Nov & Jan & Mar & May & Jul & Sep \\
\hline Absidia spinosa & - & - & - & - & - & - & - & - & - & - & 4.3 & 4.0 \\
\hline Cunnibhamella echinulata & - & - & - & - & - & - & - & 14.3 & - & - & - & - \\
\hline Mortierella sp. & - & 18.5 & - & - & - & 5.9 & - & - & - & - & - & - \\
\hline Mucor hiemalis & - & - & 11.1 & 6.2 & 8.3 & 5.9 & - & - & - & 1.4 & - & 8.0 \\
\hline Pythium sp. & - & - & - & 8.3 & 11.1 & - & - & - & - & 5.8 & - & 4.0 \\
\hline Rhizopus stolonifer & - & - & 7.4 & 4.2 & 5.5 & 7.8 & - & - & 7.1 & 4.3 & - & 4.0 \\
\hline Sporbolomyces roseus & - & - & - & - & - & - & - & - & - & 5.8 & - & - \\
\hline Aureobasidium pullulans & - & 37.0 & 7.4 & 8.3 & 5.5 & 9.8 & - & - & 5.3 & 4.3 & - & - \\
\hline Alternaria alternata & - & - & 14.8 & - & - & - & - & - & 10.5 & 8.7 & 8.6 & 8.0 \\
\hline Aspergillus fumigatus & - & - & - & - & - & - & - & - & - & 4.3 & 4.3 & - \\
\hline A. flavus & - & - & - & 10.4 & 11.1 & 3.9 & - & - & 5.3 & 2.9 & 2.1 & 4.0 \\
\hline A. niger & - & - & - & - & - & - & - & - & 10.5 & 4.3 & 3.2 & 2.7 \\
\hline Acremonium sp. & - & - & - & - & - & - & 14.8 & 14.3 & - & - & - & 5.3 \\
\hline Botrytis cinerea & 13.3 & 22.2 & - & - & - & - & 11.1 & 16.6 & - & - & - & 5.3 \\
\hline Cladosporium cladosporiodes & - & - & - & - & - & - & - & - & - & 2.9 & 4.3 & - \\
\hline C. herbarum & - & - & 11.1 & 16.7 & 13.8 & 13.7 & - & - & 10.5 & 7.2 & 7.5 & 5.3 \\
\hline Chaetomium sp. & - & - & - & - & - & - & - & - & 8.8 & - & - & - \\
\hline Curvularia lunata & - & - & - & - & - & - & - & - & - & - & 7.5 & 6.7 \\
\hline Epicoccum purpurascens & - & - & - & - & - & - & - & - & - & - & - & 6.7 \\
\hline Fusarium oxysporum & - & - & 18.5 & 12.5 & 13.8 & 11.8 & - & - & - & - & - & 9.3 \\
\hline F. poae & - & - & - & 6.2 & 5.6 & 5.9 & - & - & - & 5.8 & 4.3 & - \\
\hline Geotrichum candidum & - & - & - & - & - & - & 13.0 & 14.3 & 10.5 & - & 6.5 & - \\
\hline Oidiodendron sp. & - & - & - & - & - & - & 7.4 & 11.9 & - & - & - & 5.3 \\
\hline Paecilomyces variotii & - & - & - & - & - & - & 13.0 & - & - & 7.2 & 7.5 & - \\
\hline Penicillium chrysogenum & - & - & - & 10.4 & 8.3 & 11.8 & - & - & - & 5.8 & 7.5 & 4.0 \\
\hline P. citrinum & - & - & - & - & - & - & - & 11.9 & 7.0 & 2.9 & 5.4 & - \\
\hline P. rubrum & - & - & 7.4 & 4.2 & - & - & 11.1 & - & 8.8 & 4.3 & 5.4 & - \\
\hline Trichoderma viride & 6.7 & 7.4 & 7.4 & - & - & 13.7 & 7.4 & 7.1 & - & 5.8 & 5.4 & 5.3 \\
\hline Verticillium sp. & 23.3 & - & - & 6.2 & - & - & 9.2 & - & 7.0 & 5.8 & 4.3 & 5.3 \\
\hline Black sterile mycelium & - & - & - & 6.2 & 11.1 & - & 5.5 & - & - & 4.3 & 4.3 & 1.3 \\
\hline White sterile mycelium & 13.3 & 14.8 & 3.7 & - & 5.5 & 9.8 & 7.4 & 9.5 & 8.8 & 5.8 & 3.2 & 5.3 \\
\hline Yellow sterile mycelium & - & - & - & - & - & - & - & - & - & - & 4.3 & - \\
\hline
\end{tabular}


TABLE 2

Index of diversity, species richness and similarity of fungi at two sites

\begin{tabular}{|c|c|c|c|c|c|}
\hline \multirow{2}{*}{$\begin{array}{l}\text { Months Polluted } \\
\text { Site }\end{array}$} & \multicolumn{2}{|c|}{ Shannon's index of diversity } & \multicolumn{2}{|c|}{ Species Richness Index } & \multirow{2}{*}{$\begin{array}{l}\text { Sorenson's } \\
\text { Index (\%) }\end{array}$} \\
\hline & Unpolluted Site & Polluted Site & Unpolluted Site & Similarity & \\
\hline November & 0.71 & 0.97 & 4.0 & 5.57 & 46.15 \\
\hline January & 0.64 & 0.88 & 3.14 & 5.23 & 36.36 \\
\hline March & 0.95 & 1.05 & 8.38 & 7.82 & 60.0 \\
\hline May & 1.03 & 1.33 & 8.30 & 12.48 & 68.96 \\
\hline July & 1.01 & 1.24 & 7.41 & 10.05 & 32.0 \\
\hline September & 1.01 & 1.24 & 7.31 & 11.44 & 51.85 \\
\hline
\end{tabular}

TABLE 3

Correlation coefficients ( $r$ ) for $\mathrm{Pb}, \mathrm{Zn}, \mathrm{Cu}, \mathrm{Cd}, \mathrm{S}$, rainfall, temperature, humidity, fungal and bacterial populations on phylloplane of Alnus nepalensis at polluted and unpolluted site

$\begin{array}{lccccccc}\begin{array}{l}\text { Sources of } \\ \text { variation }\end{array} & \text { DF } & \begin{array}{c}\text { Fungal } \\ \text { Population }\end{array} & \begin{array}{c}\text { Polluted Site } \\ \text { Population }\end{array} & \text { Rainfall } & \begin{array}{c}\text { Fungal } \\ \text { Population }\end{array} & \begin{array}{c}\text { Bacterial } \\ \text { Population }\end{array} & \text { Rainfall } \\ \mathrm{Pb} & 4 & -0.948^{* * *} & -0.834^{*} & 0.975^{* * *} & -0.351 & -0.335 & -0.551 \\ \mathrm{Zn} & 4 & -0.864^{*} & -0.969^{* *} & -0.750 & -0.581 & -0.662 & -0.946^{* *} \\ \mathrm{Cu} & 4 & -0.905^{*} & -0.897 * & -0.930^{* *} & -0.660 & -0.753 & 0.984^{* * *} \\ \mathrm{Cd} & 4 & -0.905^{*} & -0.982^{* * *} & -0.845^{*} & -0.623 & -0.690 & -0.903 * \\ \mathrm{~S} & 4 & -0.920^{* *} & -0.923^{* *} & -0.937 * * & -0.595 & -0.678 & -0.972 * * \\ \mathrm{Rainfall} & 4 & 0.901^{*} & 0.771 & - & 0.577 & 0.696 & - \\ \text { Temperature } & 4 & 0.855^{*} & 0.900^{*} & - & 0.930 * * & 0.983 * * & - \\ \text { Humidity } & 4 & 0.539 & 0.467 & - & 0.712 & 0.636 & -\end{array}$

level of pollutants. The seasonal fluctuation in CFU was due to change in pollutant's level, temperature, rainfall and relative humidity. Maximum fungal population in the month of May was correlated to the high rainfall reducing the pollutants level on the leaf surface at the polluted site. Further, the young leaves had less pollutants deposition on their surface during May compared to the matured leaves during winter months. While changes in the number of phylloplane microorganisms in unpolluted site could be related to the change in the nutritional status of leaves with age due to increased leaf leachates (Tukey 1971). The main effect of the pollution by heavy metals retained by leaves on the phyllosphere microflora was the strong inhibition of each group of microorganisms (Brighigna et al. 2000).

The marked reduction in microbial population on leaf surface due to pollution on the roadside may consequently affect the microbial colonization of leaf litter thus delaying nutrient release and decomposition. This may lead to gradual accumulation of organic matter. 


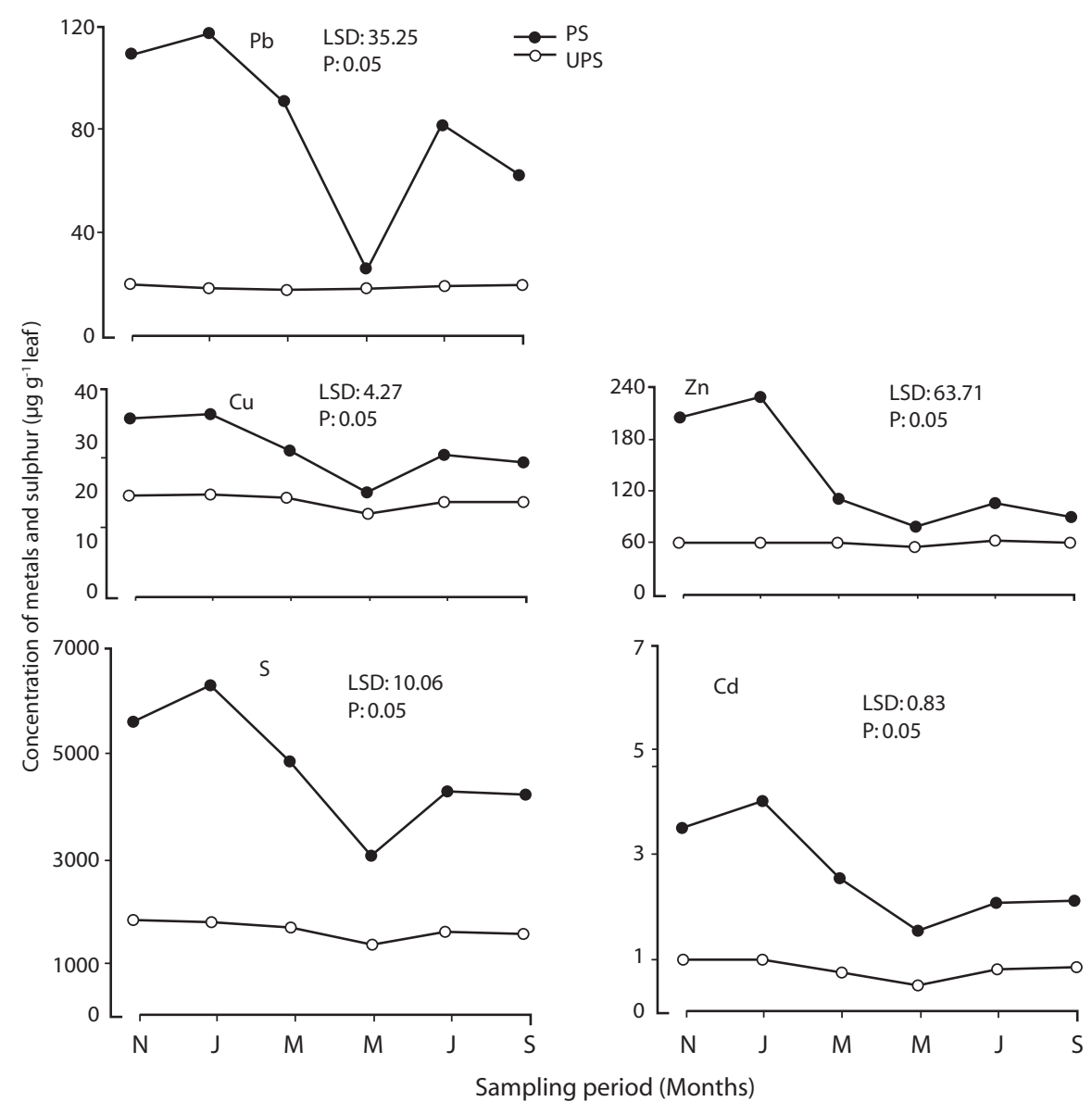

Fig. 3. Bimonthly variation in the concentration of lead, copper, zinc, cadmium and sulphur in the leaf of alder at polluted (PS) and unpolluted (UPS) sites.

\section{RESUMEN}

La región nororiental de la India está experimentando un rápido desarrollo industrial y debido a la topografía montañosa de la región, los automóviles descargan variedad de contaminantes. Actividades humanas como moler piedra y construir caminos también aumentan el polvo atmosférico y la contaminación con metales pesados. Este estudio compara microorganismos en superficies foliares del árbol Alnus nepalensis (Betulaceae). Se estudió uno sitio en una intersección de Shillong, con alta densidad de tráfico (8 000-9 000 vehículos pesados/día), tomada como el sitio contaminado, y otro en un bosque aproximadamente a $500 \mathrm{~m}$ de la carretera (sitio no contaminado). Se contabilizaron bacterias, hongos, plomo, zinc, cobre, cadmio y sulfuro. La población bacteriana era más alta en el sitio no contaminado. La población bacteriana mostró una correlación negativa significativa con el contenido de plomo, cinc, cobre, cadmio y sulfuro foliares en el sitio contaminado, mientras que en el sitio no contaminado la correlación fue insignificante. La población de hongos también fue más alta en el sitio no contaminado. Un total de 29 especies de hongos fueron aislados A. nepalensis: 16 en el sitio contaminado y 28 en el no contaminado. Algunas especies de hongos como Mortierella sp., Fusarium oxysporum y Aureobasidium pollulans fueron dominantes en el sitio contaminado. El número de hongos y bacterias fue significativamente menor en el sitio contaminado. El coeficiente de correlación indicó un efecto perjudicial de metales como el plomo, el zinc, el cobre, el cadmio y el sulfuro en esta comunidad que habitan superficies de hojas. La especificidad de ciertos hongos al sitio no contaminado se puede atribuir a su sensibilidad a la contaminación. El predominio de Aureobasidium pollulans, Fusarium oxysporum y Mortierella sp. en el sitio contaminado puede ser debido a su resistencia a los agentes contaminadores. 
Palabras clave: Alnus nepalensis, carretera, contaminación, metales pesados, filosfera, comunidad de microorganismos.

\section{REFERENCES}

Allen, S.E. 1974. Chemical analysis of ecological materials. Blackwell Scientific, Oxford, Oxford, England.

Bewley, R.J.F. 1980. Effects of heavy metal pollution on oak leaf microorganisms. Appl. Environ. Microbiol. 40: 1053-1059.

Bewley, R.J.F. \& R. Campbell. 1980. Influence of zinc, lead and cadmium pollutants on the microflora of Hawthorn leaves. Microb. Ecol. 6: 227-240.

Brighigna, L., A. Gori, S. Gonnelli \& F. Favilli. 2000. The influence of air pollution on the phyllosphere microflora composition of Tillandsia leaves (Bromeliceae). Rev. Bio. Trop. 48: 10-18.

DeJager, E.S., F.C. Wehner \& L. Korsten. 2001. Microbial ecology of the mango phylloplane. Microb. Ecol. 42: 201-207

Dickinson, C.H. 1971. Cultural studies on leaf saprophytes. p. 129-137. In T.F. Preece \& CH Dickinson (eds.). Ecology of leaf surface microorganisms. London, London, England.

Difco-manual. 1953. Difco Laboratories. Detroit Mich, Michigan, USA.

Fritze, H. \& E. Baath. 1993. Microfungal species composition and fungal biomass in a coniferous forest soil polluted by alkaline deposition. Microb. Ecol. 25: 83-92.

Gingell, S.M., R. Campbell \& M.H. Martin. 1976. The effects of zinc, lead and cadmium pollution on the leaf surface microflora. Environ. Pollut. 11: 25-37.

Malecka-Adamowicz, M., J. Kaczanowska \& W. Donderski. 2007. The impact of landfill site in Zolwin-Wypaleniska on the microbiological quality of the air. Pol. J. Environ. Stud. 16: 101-107.

Manning, W.J. 1971. Effects of limestone dust on leaf condition, foliar disease incidence and leaf surface microflora of native plants. Environ. Pollut. 2: 69-76.

Manning, W.J. 1975. Interactions between air pollutants and fungal, bacterial and viral plant pathogens. Environ. Pollut. 9: 87-92.

Martin, J.P. 1950. Use of acid rose Bengal and streptomycin in the plate method for estimating soil fungi. Soil. Sci. 69: 215-232.
Monge-Najera, J., M.I. Gonzalez, R. Rivas \& V.H. MendezEstrada. 2002. Twenty years of lichen cover change in a tropical habitat (Costa Rica) and its relation with air pollution. Rev. Biol. Trop. 50: 309-319.

Mowll, J.L. \& G.M. Gadd. 1985. Effect of vehicular lead pollution on phylloplane mycoflora. Trans. Br. Mycol. Soc. 84: 685-689.

Proctor, J., J. Burrow \& G.C. Craig. 1980. Plant and soil chemical analyses from a range of Zimbabwean serpentine sites. Kirkia. 12: 127-139.

Saunders, P.J.W. 1971. Modification of the leaf surface and its environment by pollution, p. 81-89. In T.F. Preece \& C.H. Dickinson (eds.). Ecology of leaf urface microorganisms. London, London, England.

Saunders, P.J.W. 1973. Efects of atmospheric pollution on leaf surface microflora. Pestic. Sci. 4: 589-595.

Shannon, C.E. 1948. Mathematical theory of communication. Bell. System. Technol. J. 27: 379-423.

Smith, W.H. 1971. Lead contamination of roadside white pine. For. Sci. 17: 195-198.

Smith, W.H. 1976a. Air pollution effects on the structure and function of plant-surface microbial ecosystems, p. 75-105. In T.F. Preece \& C.H. Dickinson (eds.). Microbiology of aerial plant surfaces. London, London, England.

Smith, W.H. 1976b. Lead contamination of roadside ecosystem. J. Air. Pollut. Contr. Assoc. 6: 753-766.

Smith, W.H. 1977. Influence of heavy metal leaf contaminants on the in vitro growth of urban-tree phylloplane fungi. Microb. Ecol. 3: 231-239.

Sorenson, T. 1948. A method of establishing groups of equal amplitude in plant sociology based on similarity of species content. Det. Kong. Danske. Vidensk. Selsk. Biology. Skr (Copenhagen) 5: 1-34.

Swailesh, K.M., R.M. Hussein \& S. Abu-Elhaj. 2004. Assessment of heavy metal contamination in roadside surface soil and vegetation from the West Bank. Arch. Environ. Contam. Toxicol. 47: 23-30.

Tukey Jr., H.B. 1971. Leaching of substrates from plants, p. 67-80. In T.F. Preece \& C.H. Dickinson (eds.). Ecology of leaf surface microorganisms. London, London, England.

Zar, J.H. 1976. Biostatistical Analysis. Prentice Hall, London, England. 
